\title{
Assessment of Conceptual Demands of Basic Science Curriculum and Students' Cognitive Development in Plateau State, Nigeria
}

\author{
Ozoji Bernadette Ebele, Mankilik Mangut \\ Department of Science and Technology, Department of Science and Technology Education, \\ University of Jos, Nigeria
}

\begin{abstract}
The study assessed the conceptual demands of the basic science curriculum and students' cognitive development in Plateau State, Nigeria. A sample of 622 junior secondary three students, selected from 5763 students in three senatorial districts of Plateau State was used for the study. The descriptive design was adopted in the study. The sample was selected with proportionate stratified sampling technique. A curriculum Analysis Taxonomy (CAT) and Science Reasoning Tasks (SRTS)11 were used for data collection. The independent ratings of the CAT showed a consensus of $87.00 \%$ while the reliability index of the SRTs $11 \mathrm{~s}$ was 0.72. Two research questions and one hypothesis guided the study. The research questions were answered with frequencies and percentages while the hypothesis was tested with Chi square statistic. The results of the study showed that $64.00 \%$ of the concepts in the basic science curriculum were not understood by the students. Furthermore, a significant relationship was found to exist between the conceptual demands of the integrated science curriculum and students' cognitive development. The contribution of the study to education is for relevant stake holders to devise ways of enhancing students' cognitive development, to enable them understand the concepts in their basic science curriculum.
\end{abstract}

\section{Introduction}

Assessment with regard to education refers to the process of gathering and discussing information in order to obtain a deep understanding of what students know and understand from educational experiences as well as for making decisions. To [9], assessment is the systematic basis for making inferences about the learning and development of students, the process of defining, selecting, designing, collecting, analysing, interpreting and using information to increase students' learning and development. Assessment results are also used to improve subsequent learning [10]. From these definitions of assessment, it is seen as a sine qua non for effective science delivery and overall development of students.
Science is an important enterprise which nations of the world depend on as a hub for socioeconomic development and technological advancement. There is no gain saying the fact that science education is receiving a lot of emphasis globally on account of its relevance to life and the society. It is imperative therefore, that every individual should have some basic knowledge and skills of science in order to live successfully in this modern age that is dominated by scientific and technological ideas, as well as, their products and processes. No wonder Turner [16] sees Science as representing one end of a vital pipeline which channels science-oriented students from secondary to postsecondary institutions and a pipeline that will eventually culminate in the provision of highly trained scientific and technological personnel who will by and large, contribute to economic well- being of the nation and global competitiveness.

It is for the fore-going reasons that in Nigeria science education is accorded a compulsory status at the basic level of education. At this stage, science is taught as basic science and technology at the lower and middle basic level (primary 1 to 3 , then 4 to 6 ), while at the upper basic level (junior secondary 1 to 3 ), it is taught as basic science.

Despite the pride of place that science occupies in national development, literature is replete with evidences of the claim of a low level of achievement by students in science in Nigeria [7,3]. This claim is confirmed by the West African Examinations Council (WAEC) reports of 2007 to 2013 which showed high rates of failure in science subjects in the West African Secondary School Certificate Examinations. The situation is the same at the junior secondary school level, where an analysis of integrated science results of some public junior secondary schools in Jos, Nigeria for five consecutive years showed poor performance outcomes, with most students scoring less than $50.00 \%$.

A number of studies aimed at investigating the likely causes of poor achievement by students in science in Nigeria and how such a problem could possibly be reduced have been conducted $[1,7,13]$. However, not much appear to have been done in the area of ascertaining the conceptual demands made by the activities and objectives of the science 
curriculum on students, particularly at the junior secondary school level, and, whether or not these conceptual demands are in tandem or at variance with students' cognitive development/thinking levels.

Cognitive development refers to the development of the thinking systems of the mind that involve language, mental imagery, thinking, reasoning, problem-solving and mental development [111]. [5] see cognitive development having to do with students' operational stages and thinking abilities. These definitions indicate that cognitive development is concerned with the growth of knowledge and thinking abilities within a child as a result of his interaction with the environment.

Be that as it may, [14] proposed that cognitive growth occurs in stages, namely, sensorimotor, preoperational, concrete operational and formal operational stages. The stages according to [16], have characteristic features that make them distinctly different from one another. A child at the concrete operational stage (about 7 to 11 years) for instance, can think in concrete terms, serialize or group ideas according to specific attributes such as size, weight and volume, but cannot engage in abstraction.

Formal operational stage of cognitive development (about 12 years and above) is characterized by abstract and reflective thinking; deductive reasoning and systematic planning, among others. Some of the features of formal operational thinking otherwise known as higher order thinking skills are considered as vital for the understanding of mathematics and science concepts, many of which are abstract in nature $[4,14,1]$. Incidentally, findings from studies conducted across the globe seem to show that a large proportion of secondary school students operate below the formal operational level of thought $[16,6]$ It is against the fore-going backdrop that the study assessed the conceptual demands of the basic science curriculum and students' cognitive development and their performance in Plateau State, Nigeria.

\section{Objectives of the Study}

The main objective of the study was to assess the conceptual demands made of the basic science curriculum. The study also investigated the levels of cognitive development of the JSS three students and the relationship between the levels of conceptual demands of the basic science curriculum and students' cognitive development in Plateau State, Nigeria.

The following research questions guided the investigation and a hypothesis was tested for significance at 0.05 level:

i. What levels of demand does the basic science curriculum make on JSS three students? ii. What are the levels of cognitive development of JSS three students?

iii. There is no significant relationship between the levels of conceptual demand of the basic science curriculum and JSS three students' cognitive development.

\section{Theoretical Framework}

The study was anchored on Piaget's theory of cognitive development. [14] in his theory of cognitive development outlined the sequence in the development of the child's scientific and logical thought. The sequence shows how children at different levels of cognitive development cope with scientific and logical thought. The position held by Piaget is that cognitive growth occurs in stages which have precise age limits attached to them. These are sensori-motor stage (0-2years), preoperational stage (2-7years), concrete operational stage (7-11years) and formal operational stage (1116years).

According to Piaget's theory, in any teaching/learning situation, any information that is at variance with the learner's given schema or knowledge structures is not assimilated, that is, it does not result in cognitive growth. The implication of Piaget's theory to basic science instruction is that the curriculum must be matched with the child's level of cognitive development for any lesson to be understood. The theory further implies that science teachers should identify the levels of cognitive development an individual child is operating on, in order to use appropriate instructional techniques to enhance the intellectual ability for improved achievement outcomes in school subjects particularly, science.

\section{Methodology}

The study employed the descriptive survey design. The design was used to obtain information from the national core curriculum for Junior Secondary Schools (Federal Ministry of Education, FME, 1985) and JSS three students. The population of the study comprised 5763 JSS three students distributed among 272 public junior secondary schools in three senatorial districts of Plateau State Nigeria. The sample for the study consisted of 622 JSS three students selected from 3 out of 24 schools that had comparable facilities, such as, science laboratories and qualified science teachers.

The students were selected using the proportional stratified sampling technique. This class of students was used because the students were expected to be operating at the formal operational level of thought by virtue of their age bracket (about 12 to 19 years) according to Piagetian perspective. 
Two instruments were used for data collection, namely, a Curriculum Analysis Taxonomy (CAT) developed by the researcher and Science Reasoning Tasks II (SRTs 11) adopted from [2]. In developing the CAT, the researcher carefully studied the basic science syllabus in the core curriculum for junior secondary schools. That, enabled the researcher to select four content areas for the study, namely, atomic structure, heredity, acids, bases and salts, and energy conversion and transfer, which from experience are known to be areas students perceive as difficult.

These selected content areas in addition to the performance objectives and students activities were outlined and rated by the researcher in line with the CAT. The rating was scrutinized by two science educators in the Faculty of Education, University of Jos, Nigeria to ascertain the extent to which the performance objectives or students' activities matched the corresponding cognitive developmental levels assigned to them.

A consensus of $87 \%$ was reached by the scrutinizers regarding the validity of the CAT. The SRTs II was administered to the students for one hour. The scripts were collected from the students at the end of the exercise, scored with an appropriate scoring guide and the scores collated. The reliability index of the SRTs II was found to be 0.72 using the Cronbach alpha method.

\section{Results}

The results of the study are presented on the basis of the research questions and hypothesis as follows:

\subsection{Research Questions One}

What are the levels of demand made by the basic science curriculum on JSS three students?

Table 1. Percentage levels of demands made by the Basic Science Curricular Activities on JSS Three Students.

\begin{tabular}{|c|c|c|}
\hline $\begin{array}{l}\text { Cognitive Development Levels of } \\
\text { Students }\end{array}$ & $\begin{array}{l}\text { Number of Curricular } \\
\text { Activities }\end{array}$ & $\begin{array}{l}\text { Percentage Number of } \\
\text { Curricular Activities }\end{array}$ \\
\hline Pre-operational (2A level) & 0 & 0.00 \\
\hline Early concrete operational level (2A) & 9 & 36.00 \\
\hline Mid concrete operational level (2A/2B) & 0 & 0.00 \\
\hline Late concrete operational level (2B) & 0 & 0.00 \\
\hline Transitional level (2B/3A) & 0 & 0.00 \\
\hline Early formal operational level (3A) & 8 & 0.32 \\
\hline Late formal operational level (3B) & 8 & 0.32 \\
\hline Total & 25 & 100.00 \\
\hline
\end{tabular}

Results in Table 1 show that $9(36.00 \%)$ of the 25 curricular activities in the four content areas used in the study made conceptual demands on JSS three students at the concrete operational of development level while $16(64.00 \%)$ out of the 25 curricular activities made conceptual demands on the students at the formal operational level of cognitive development.

\subsection{Research Question Two}

What are the cognitive developmental levels of JSS three students?

Table 2. Percentage Distribution of JSS Three students according to Cognitive Developmental Levels

\begin{tabular}{|c|c|c|}
\hline \begin{tabular}{l|l}
$\begin{array}{l}\text { Cognitive } \\
\text { Students }\end{array}$ & Development Levels of \\
\end{tabular} & $\begin{array}{l}\text { Number of Curricular } \\
\text { Activities }\end{array}$ & $\begin{array}{l}\text { Percentage Number } \\
\text { Curricular Activities }\end{array}$ \\
\hline Pre-operational level (1) & 147 & 23.63 \\
\hline Early concrete operational level (2A) & 331 & 53.22 \\
\hline Mid concrete operational level $(2 \mathrm{~A} / 2 \mathrm{~B})$ & 125 & 20.10 \\
\hline Late concrete operational level (2B) & 14 & 2.25 \\
\hline Transitional level (2B/3A) & 4 & 0.64 \\
\hline Early formal operational level (3A) & 1 & 0.16 \\
\hline Late formal operational level (3B) & 0 & 0.00 \\
\hline Total & 622 & 100.00 \\
\hline
\end{tabular}

Results in Table 2 show that 147(23.63\%) of the students were operating at the preoperational level of cognitive development, $331(53.22 \%)$ of them were at the early concrete operational level, $125(20.10 \%)$ at the mid concrete operational level, $14(2.25 \%)$ at the late concrete operational level, while $4(0.64 \%)$ of the students were at the transitional level of cognitive development. Only one student $(0.16 \%)$ was found operating at the early formal operational level. In summary, the results in Table 2 show that a total of $621(99.20 \%)$ of the JSS three students used in the study were operating below the formal operational level of thought. This means that only one student was operating at the formal operational level of thought.

\section{Hypothesis}

There is no significant relationship between the levels of conceptual demand of the basic science curriculum and the cognitive development of JSS three students.

Table 3. Result of Chi Square Test of Difference on Conceptual Demands of the Basic Science Curriculum and Students' Cognitive Development.

\begin{tabular}{|c|c|c|c|c|c|}
\hline $\begin{array}{l}\text { Cognitive } \\
\text { developmental levels/ } \\
\text { Levels of conceptual } \\
\text { demand }\end{array}$ & $\begin{array}{l}\text { No. of } \\
\text { Activities }\end{array}$ & curricular & No. of students & $x^{2}-\mathrm{cal}$ & $x^{2}$-crit \\
\hline $1 A-2 B / 3 A$ & 10 & & 621 & & \\
\hline $3 \mathrm{~A}-3 \mathrm{~B}$ & 15 & & 01 & 634.6 & 9.49 \\
\hline
\end{tabular}

The data on Table 3 show that the calculated $\mathrm{x} 2$ value of 634.61 is greater than the critical $x 2$ - value of 9.49 at 620 degree of freedom, meaning that there was a significant relationship between the levels conceptual demands of the basic science curriculum on JSS three students and their cognitive 
development. The null hypothesis was therefore rejected.

\section{Discussion of Findings}

The results in Table 1 reveal that $64.00 \%$ of the curricular activities in the Nigerian basic science syllabus for JSS Three were formal concepts which according to [10] require the use of formal operational level of thinking/cognitive development. The results in Table 2 revealed that most of the JSS three students $(99.20 \%)$ were operating below the formal operational level of cognitive development. This finding is consistent with the results of studies conducted by [15],[6]which showed a similar lag in cognitive development among secondary school students in science, where a high proportion of the students were found operating at the concrete operational level of cognitive development. The finding is further consistent with that of Gyuse (1990) in which $75.60 \%$ of them Nigerian Chemistry curriculum demanded formal operational thinking on senior secondary one students.

Furthermore, a significant relationship was found to exist between the levels of conceptual demand of the basic science curriculum and students' levels of cognitive development. The findings seem to explain why students find their basic science content difficult to understand. It further seems to explain why students perform poorly in science examinations. The findings of the study imply that $64.00 \%$ of the basic science content in the JSS three curriculum was not understood by the students, because this content made conceptual demand on students at the formal operational level of thinking, whereas the students were mostly operating at the concrete operational level of thought. Therefore, JSS three students majority of whom were concrete thinkers seemed to be saddled with the problem and frustration of learning abstract basic science content that require the use of formal operational thought which they were cognitively not ready for.

\section{Recommendations and Conclusion}

The following recommendations and conclusion were made in the light of findings of the study.

- Basic Science teachers should employ effective and innovative instructional techniques which are capable of enhancing the thinking capacities of students to such an extent that they would learn formal concepts in the basic science curriculum.

- Students should be involved in meaningful group activities or cooperative learning by their teachers during science lessons. This could enable them engage in critical and reflective thinking as they share ideas. Moreover, cooperative learning environments are known to stimulate thinking and generation of ideas which subsequently result in enhanced cognitive development and achievement outcomes in school subjects.

\section{Educational Importance}

The importance of the findings of the study to education is that it will enable science teachers to find out the cognitive developmental/thinking levels of the students they teach by the use of science reasoning tasks. It will also help them to devise effective and innovative strategies for enhancing cognitive growth to enable the students understand the abstract concepts in their science curriculum. This is vital because of the assumption that secondary school students employ formal operations which the study has refuted. The findings will furnish policy makers and curriculum developers with information on how to assist teachers and students develop teaching and learning skills for better cognitive achievement in examinations.

\section{References}

[1] Adejoh, M.J. (1997). The relationship between students' level of cognitive development and the learning of some biological concepts: A case study of selected secondary schools in Jos North Local Government Area of Plateau State. Unpublished Masters Thesis, University of Jos.

[2]. Adey, P.S \& Shayer, M. (1990). Accelerating the development of formal thinking in middle and high school students. Journal of Research in Science Teaching, 27 (3), 267-285.

[3] Ajagun, G.A (2006). Towards good performance in science examinations. Nigerian Journal of Teacher Education and Teaching, 2(1), 117-125.

[4] Akinmade, C.T.O (1992). Teaching integrated science, concepts to the gifted child. Journal of the Science Teachers' Association of Nigeria, 27 (2), 84-97.

[5] Bybee, R.W. \& Sund, B.R. (1990). Piaget for educators. Illinois: Waveland press.

[6] Cephni, S. Ozsevgec, T \& Cerrah, L. (2004). Turkish middle school students' cognitive developmental levels in science. Asia - Pacific Forum on Science Learning and Teaching, 5(1), 1-22.

[7] Chukwuneke, B.U. \& Nwachukwu, C.O. (2005). State and Future of education in Nigeria. InJ.D. Afe \& G.C. Edozie (Eds.) Book of abstracts and lead papers (pp. 5859) Asaba Nigeria:West and Solomon Publishing Company.

[8] Cognitive development: Not an automatic process. Retrieved on June 28, 2006 from http://www.audiobox.com.cognitivedevelopment.htm. 
[9] Erwin (1991). Assessing student learning and development: A guide to the principles, goals and methods of determining college outcomes. Jessey-Bass.

[10] Huba, M. E \& Freed, J. E. (2000). Learner-centred assessment on college campuses: studying the focus from teaching to learning. Allyn \& Bacon.

[11] Lawson, A.E. (1985). A review of research on formal reasoning and science teaching, 22 (7),567 - 617.

[12] Ncharam, S.E. (2000). A study of students' perceived difficult concepts in JSS III Nigerian Integrated Science Project content in Plateau State. The Jos Journal of Education, 5(1), 107-112.

[13] Obi, C.C. (2003). The relative effectiveness of concept mapping and schematic modeling on students' achievement in physics. Unpublished Ph.D dissertation, University of Benin,Nigeria.

[14] Ozoji, B.E. (2014). Effects of concept mapping technique on students' cognitive development in Nigeria: Implications for science and technology instruction. Stemplanet 1 (1), 1-10.

[15] Piaget, J (1961). The stages of development of the child. London: Routledge and Kegan Paul.

[16] Schemesh, M., Eckstein, S.F. \& Lazarowitz, R. (1992). An experimental study of thedevelopment of formal reasoning among secondary school students. School Science and Mathematics, 92, 26-30.

[17] WAEC (2007-2013). Chief examiner's report in Nigeria. 